Article

\title{
Turtles From an Arkadelphia Formation-Midway Group Lag Deposit (Maastrichtian-Paleocene), Hot Spring County, Arkansas, USA
}

\author{
Martin A. Becker ${ }^{1, *}$, Harry M. Maisch, IV ${ }^{2}$ and John A. Chamberlain, Jr. ${ }^{2,3}$ \\ 1 Department of Environmental Science, William Paterson University, 300 Pompton Road, Wayne, \\ NJ 07470, USA \\ 2 Doctoral Program in Earth and Environmental Science, City University of New York Graduate Center, \\ 365 Fifth Ave, New York, NY 10016, USA; hmaisch@gc.cuny.edu (H.M.M.); \\ johnc@brooklyn.cuny.edu (J.A.C.) \\ 3 Department of Earth and Environmental Sciences, Brooklyn College, City University of New York, \\ 2900 Bedford Avenue, Brooklyn, NY 11210, USA \\ * Correspondence: beckerm2@wpunj.edu; Tel.: +1-973-7200-2721
}

Academic Editor: Jesus Martinez-Frias

Received: 23 June 2016; Accepted: 6 September 2016; Published: 14 September 2016

\begin{abstract}
The Arkadelphia Formation-Midway Group (Maastrichtian-Paleocene) contact near Malvern, Arkansas preserves a K-Pg boundary assemblage of turtle species consisting of skull, shell, and non-shell postcranial skeletal elements. The Malvern turtles are preserved within a coquina lag deposit that comprises the basalmost Midway Group and also contains an abundance of other reptiles, as well as chondrichthyans, osteichthyans, and invertebrates. This coquina lag deposit records a complex taphonomic history of exhumation and reburial of vertebrate skeletal elements along a dynamic ancestral shoreline in southwestern Arkansas during the late Cretaceous-early Paleocene. Based on stratigraphic occurrence, the Malvern turtle assemblage indicates that these marine reptiles were living at or near the time of the K-Pg mass extinction and represent some of the latest Cretaceous turtles yet recovered from the Gulf Coastal Plain of the United States.
\end{abstract}

Keywords: turtles; K-Pg boundary section; Arkansas; Arkadelphia Formation; Midway Group

\section{Introduction}

To date, only a few published reports identify the occurrence of fossil turtles from the Late Cretaceous of Arkansas. The earliest of these reports was written over half a century ago [1], and described a new species of turtle from the Brownstone Formation which Schmidt named Podocnemis barberi. Four years later, Schmidt [2] described two additional turtle species, Phyllemys barberi and Catapleura arkansasensis from the Marlbrook Marl. All of Schmidt's species identifications were based on nearly complete carapaces and plastra. The present report identifies an assemblage of skull, shell, and non-shell postcranial turtle skeletal elements of uncertain taxonomic status. This turtle assemblage consists of nineteen specimens preserved in matrix and was recovered from a coquina lag deposit composing the basalmost Midway Group along the Ouachita River in Hot Spring County, Arkansas (Figures 1 and 2). 

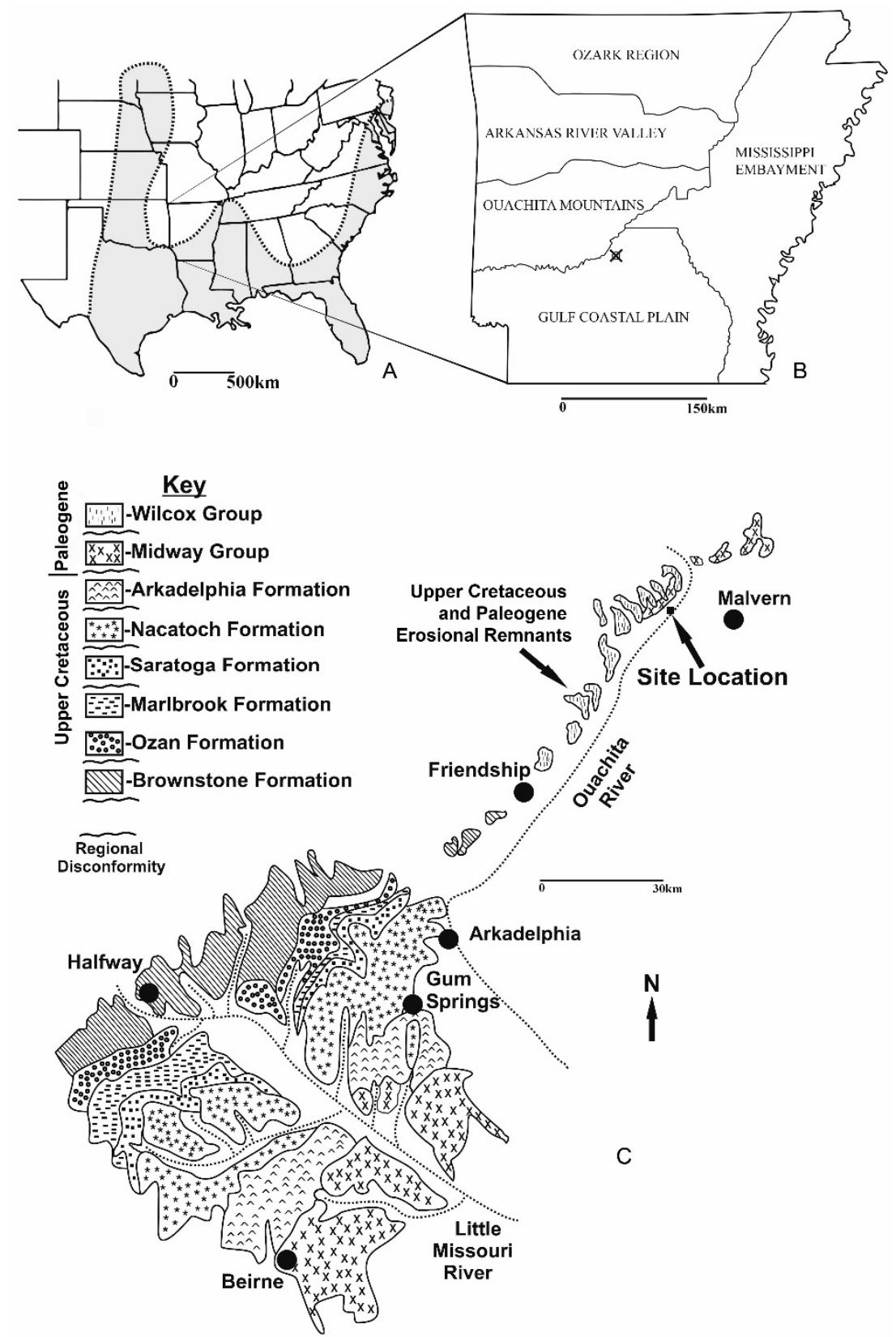

Figure 1. Location maps for the Arkadelphia Formation-Midway Group (late MaastrichtianPaleocene) turtles from Hot Spring County, Arkansas (modified from Becker et al. [3]). (A) Late Maastrichtian (Jeletzkytes nebrascensis Zone) paleogeographic reconstruction of the Atlantic and Gulf Coastal plains and Western Interior Seaway; (B) physiographic provinces in Arkansas with turtle site discussed in this study indicated by (X); (C) geologic map and stratigraphic column of Upper Cretaceous and Paleogene formations in the study area of southwestern Arkansas and Arkadelphia Formation-Midway Group turtle site discussed in this study identified by arrows.

Prior studies indicate that this lag deposit is part of a Cretaceous-Paleocene boundary section in the region [3-5] and provides excellent time control for the age of these turtle specimens. While the exact origin of the Malvern turtle lag may be the result of impact generated tsunamis, third order sea level cyclicity or some combination of both these processes, the stratigraphic occurrence of this turtle assemblage indicates that these marine reptiles were living at or near the time of the K-Pg mass extinction, and represent some of the latest Cretaceous turtles yet recovered from the Gulf Coastal Plain of the United States. 


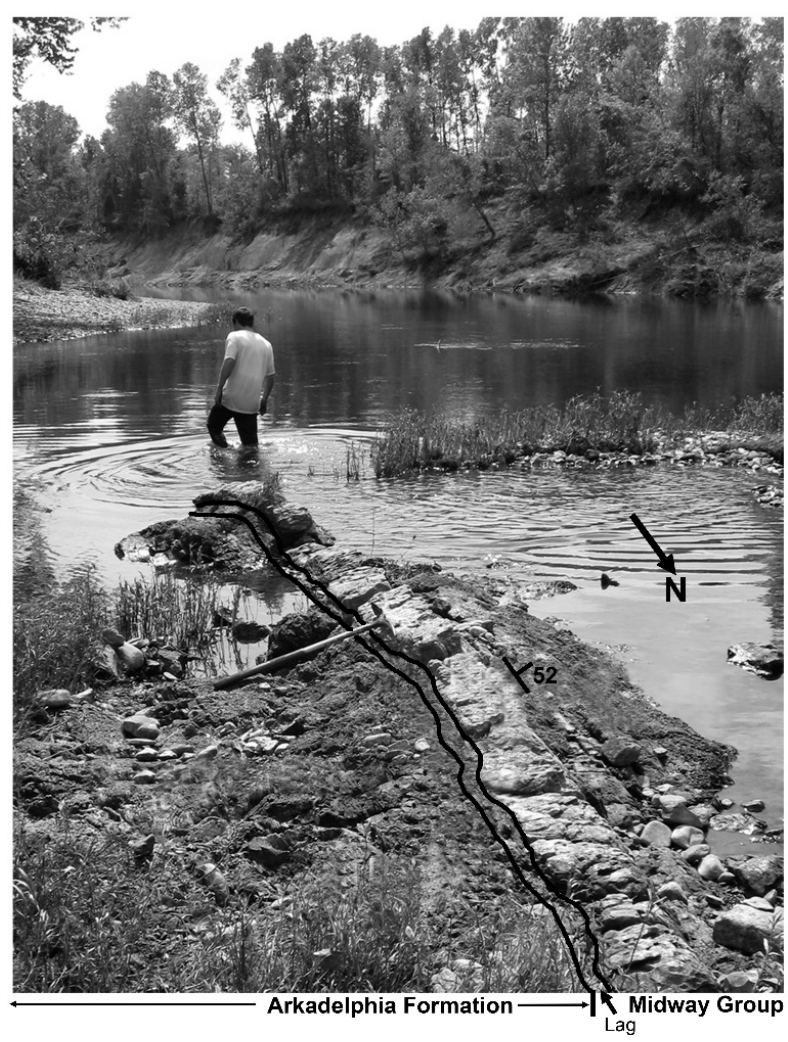

Figure 2. Outcrop exposure along the Ouachita River of the upper Arkadelphia Formation and basalmost Midway Group in Hot Spring County, Arkansas. Note strike and dip and steep inclination of the bedding relative to river water flow. Small arrow indicates the stratigraphic position of the lag deposit from which the turtle fossils in this study were recovered. Pick axe is approximately $1 \mathrm{~m}$ and the person is $1.8 \mathrm{~m}$ (Modified from Becker et al. [4]).

\section{Age of the Arkadelphia Formation-Midway Group Contact}

Multiple lines of evidence support a Maastrichtian-Paleocene age assignment for the Arkadelphia Formation-Midway Group contact near Malvern, Arkansas. This evidence includes: foraminifera [6]; calcareous nannofossils [7]; palynology [8]; dinoflagellates [9]; ostracods [10]; ammonites [7]; chondrichthyans [3,11]; osteichthyans [4,12]; plesiosaurs [5]; magnetostratigraphy [13]; and geologic mapping [14,15]; Additional discussion on the lithology and age of the Arkadelphia Formation and Midway Group in southwestern Arkansas can be found in the geologic map of Arkansas by Haley et al. [14] and in the accompanying stratigraphic summary by McFarland [16].

\section{Geologic Setting}

The coquina lag deposit from which the Malvern turtles were recovered was first described in a study documenting Late Cretaceous chondrichthyans [3] and in subsequent studies of osteichthyans [4] and plesiosaurs [5]. The best outcrop exposure of this coquina lag known to date occurs on a small island in the Ouachita River (Figure 2), totally covered by water except during times of low water flow. This island outcrop reveals a disconformable contact where individual beds of the uppermost Arkadelphia Formation, the lag deposit comprising the basalmost Midway Group, and beds of the lower Midway Group above the lag strike to the North and dip at a steep angle to the West. These beds represent loss of original horizontality during syn-depositional and post-depositional deformation (Figure 2).

At the outcrop depicted in Figure 2, the uppermost Arkadelphia Formation is a dark gray, thinly bedded micaceous marl with occasional lenses of glauconitic sands, bivalve shells and infrequent 
chondrichthyan and osteichthyan teeth. The contact of the coquina lag deposit with the underlying Arkadelphia Formation is sharp and undulatory, and can be recognized by a prominent lithology change from the dark-colored, micaceous marl of the Arkadelphia Formation to a thick-bedded coquina lag with interbedded micrite, and occasional lenses of fine-grained, cross-bedded quartz sand and rip-up clasts of Arkadelphia composition. The coquina lag comprises the basalmost Midway Group, is laterally discontinuous, and varies in thickness from a few centimeters to over $30 \mathrm{~cm}$ thick where it outcrops. The uppermost surface of the coquina lag can be identified by the numerous, well-rounded quartz and phosphate pebbles, as well as chondrichthyan and osteichthyan teeth and plesiosaurs remains [3-5]. The turtle assemblage described in this report was also recovered from this surface.

Directly above the coquina lag, interbedded sandy, gray carbonaceous marls and dense, micritic limestone typical of the Midway Group are exposed and continue in stratigraphic order to the West along the high angle of dip. One of these micrites, lying immediately above the lag, is clearly visible in Figure 2. Directly across the interstate and adjacent to the field site, Paleocene chondrichthyan and osteichthyan teeth belonging to the Midway Group occur in recent highway excavations [17] and are also exposed approximately $3 \mathrm{~km}$ to the northeast along strike in bluffs adjacent to a shopping plaza [11,12].

\section{Field Methods}

All nineteen turtle specimens identified in this paper were collected during the last decade of fieldwork at the Malvern, Arkansas site along with other vertebrates as reported in [3-5]. The turtle material was recovered directly from the basalmost Midway Group lag deposit during times of low water flow and by snorkeling and scuba diving the river bed (Figures 2 and 3). Most skull, limb, carapace and plastral elements are preserved on slabs of coquina lag collected from the river bed, and required a minor amount of laboratory cleaning and preparation to expose additional bone surfaces and suture edges.

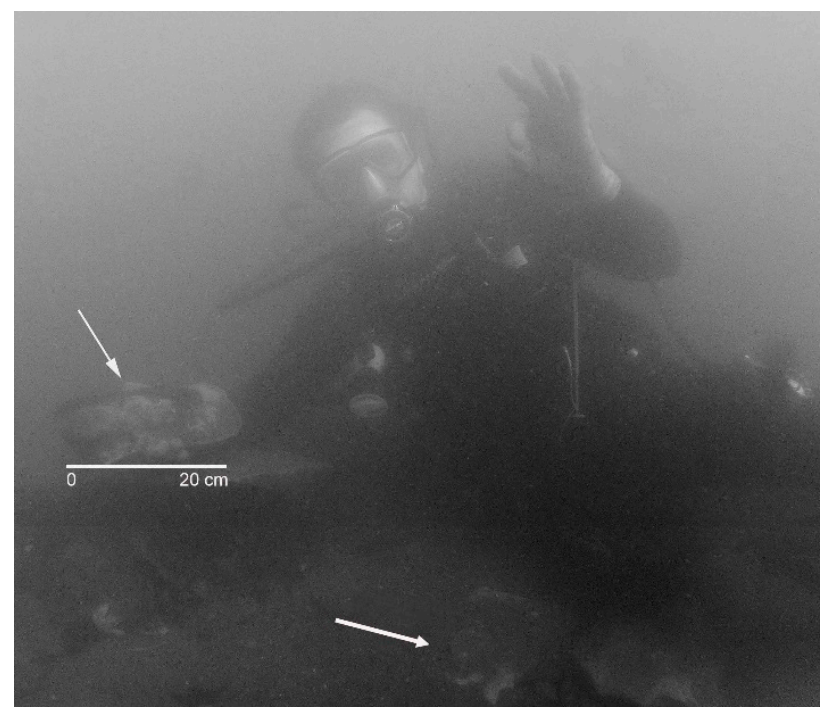

Figure 3. Scuba diving recovery of turtle peripherals (NJSM GP23413) described in this study. The arrow below the diver points to large coquina blocks of the lag deposit eroded and transported directly downstream from the adjacent outcrop exposure depicted in Figure 2. Scale Bar $=20 \mathrm{~cm}$.

\section{Repository}

Turtle specimens have been reposited in the fossil vertebrate collections of the New Jersey State Museum and have the catalogue numbers NJSM GP 23395; 23400-23404; 23406; 23408; 23409; 23411-232418; 23627-23628 (Figures 4-8). 

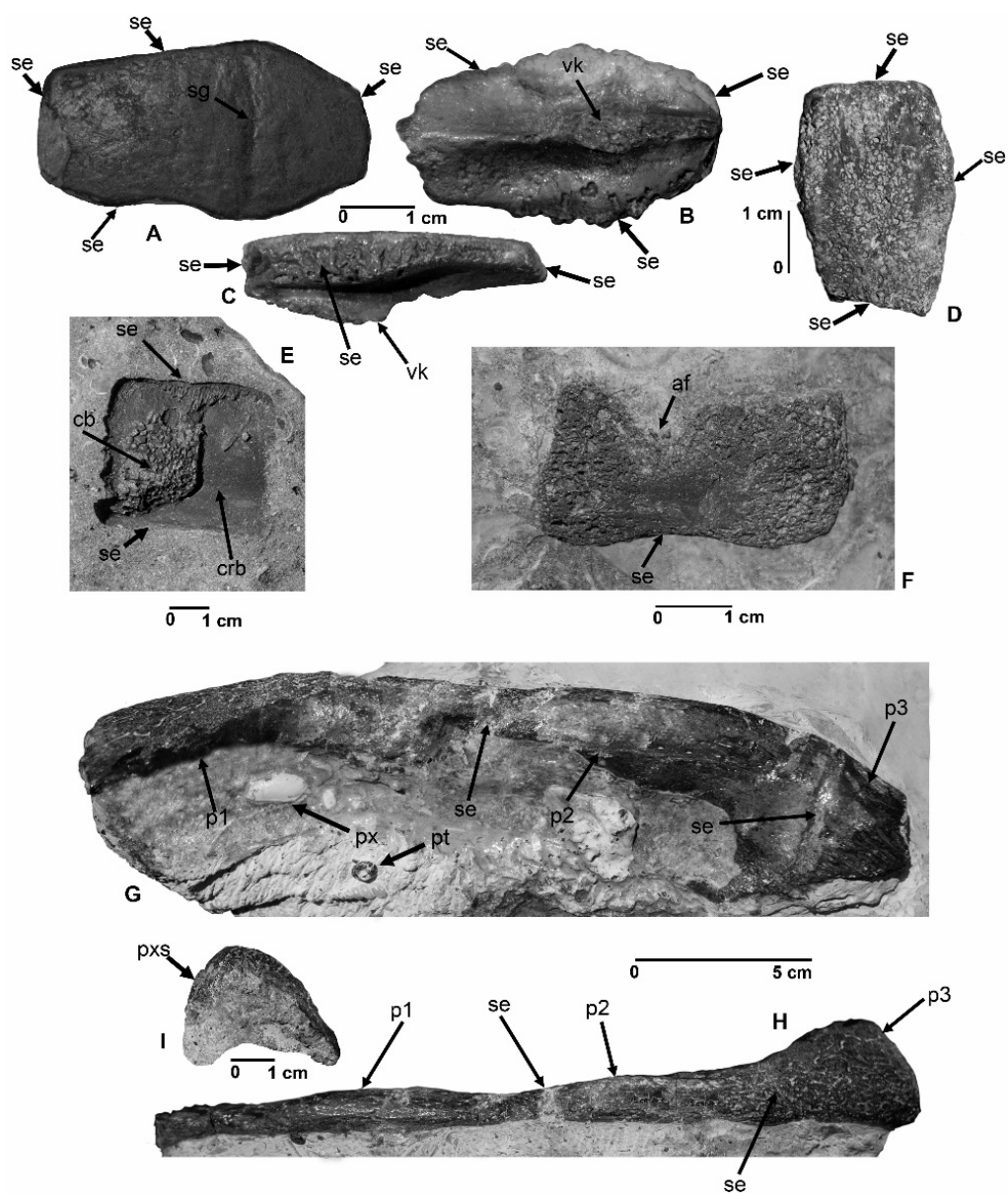

Figure 4. Turtle neurals and peripherals from the basalmost Midway Group lag deposit, Hot Spring County, Arkansas. (A-C) neural (NJSM GP23416) in exterior (A), interior (B), and cross-section (C) views; (D) neural (NJSM GP23408) in exterior view; (E) peripheral (NJSM GP23402) in interior view; (F) peripheral (NJSM GP23404) in interior view; (G-I) peripherals (NJSM GP23413) in interior (G), exterior edge $(\mathbf{H})$, and cross-section (I) views. Scale bars in $\mathbf{A}-\mathbf{F} ; \mathbf{I}=1 \mathrm{~cm} ; \mathbf{G}-\mathbf{H}=5 \mathrm{~cm}$. Abbreviations: af: articular foramen, cb: cancellous bone, crb: cortical bone, p1-p3: perpherials, pt: pycnodont tooth, px: pelecypod steinkern, pxs: peripheral cross-section, se: sutural edge, sg: sulcus groove, vk: ventral keel.

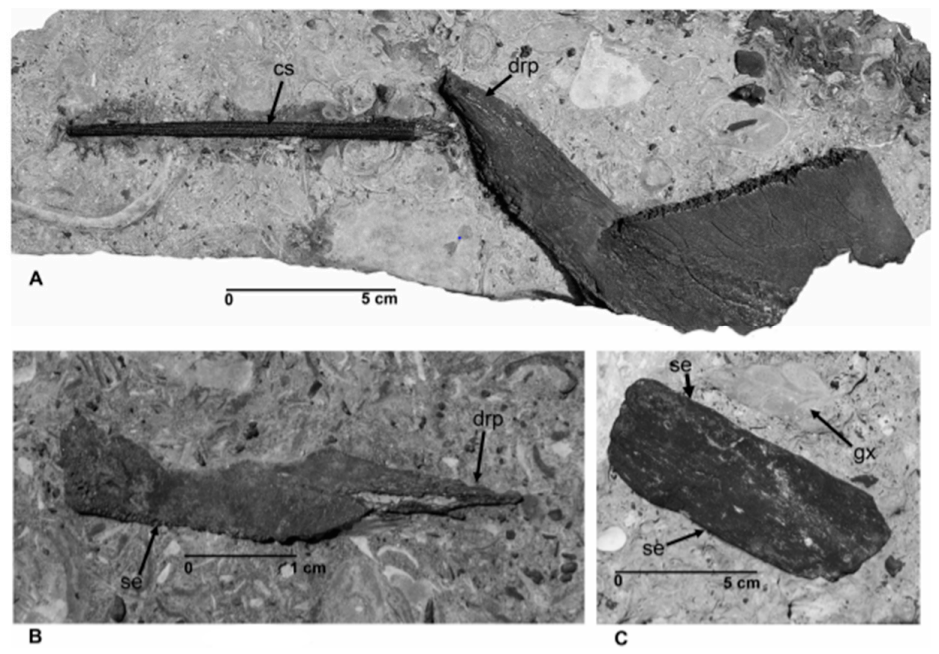

Figure 5. Cont. 

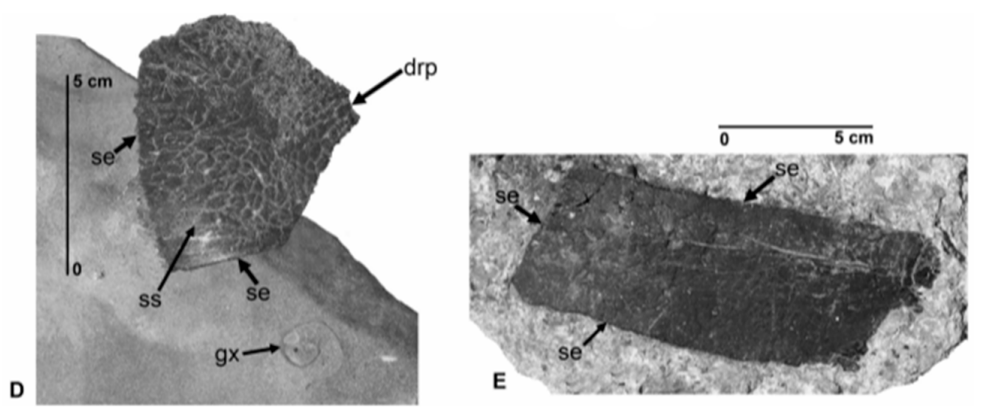

Figure 5. Turtle costals from the basalmost Midway Group lag deposit Hot Spring County, Arkansas. (A) Costal (NJSM GP23411) in exterior view; (B) costal (NJSM GP23403) in interior view; (C) costal (NJSM GP23401) in interior view; (D) costal (NJSM GP23395) in exterior view; (E) costal (NJSM GP23406) in exterior view. Scale bars in A, C-E $=5 \mathrm{~cm} ; \mathbf{B}=1 \mathrm{~cm}$. Abbreviations: cs: Cylindracanthus rostrum, drp: distal rib projection, gx: gastropod cross-section, se: sutural edge, ss: surface sculpturing.

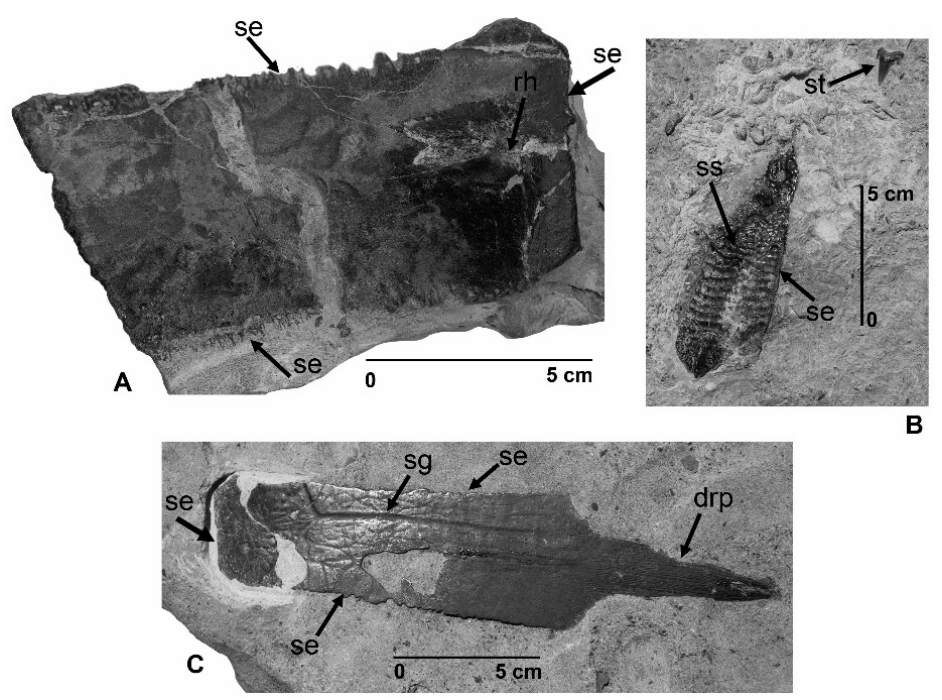

Figure 6. Turtle costals from the basalmost Midway Group lag deposit Hot Spring County, Arkansas. (A) Costal (NJSM GP23414) in interior view; (B) costal (NJSM GP23628) in exterior view; and (C) costal (NJSM GP23415) in exterior view. Scale bars in A-C $=5 \mathrm{~cm}$. Abbreviations: drp: distal rib projection, rh: rib head, se: sutural edge, sg: sulcus groove, ss: surface sculpturing, st: shark tooth.

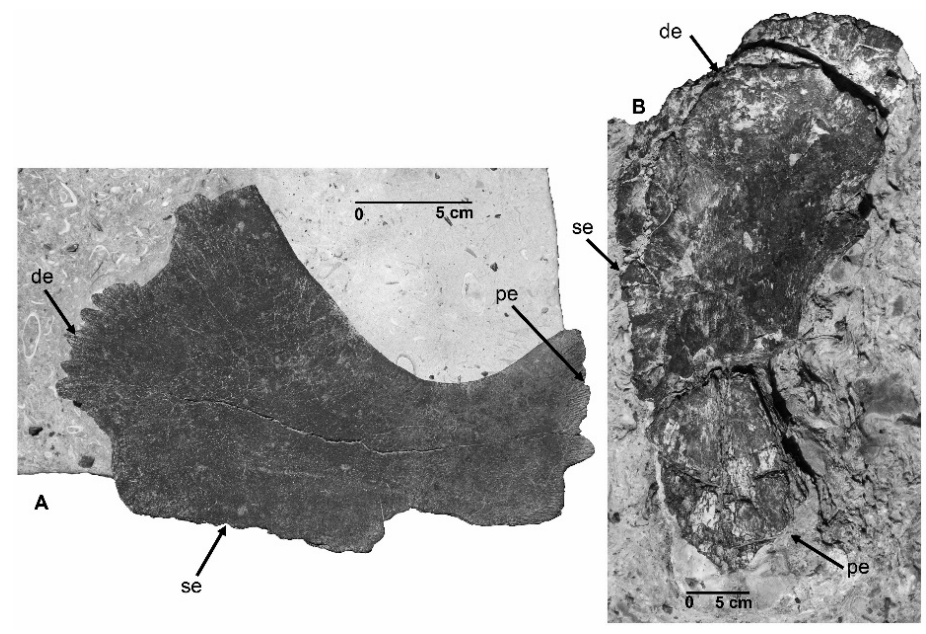

Figure 7. Cont. 

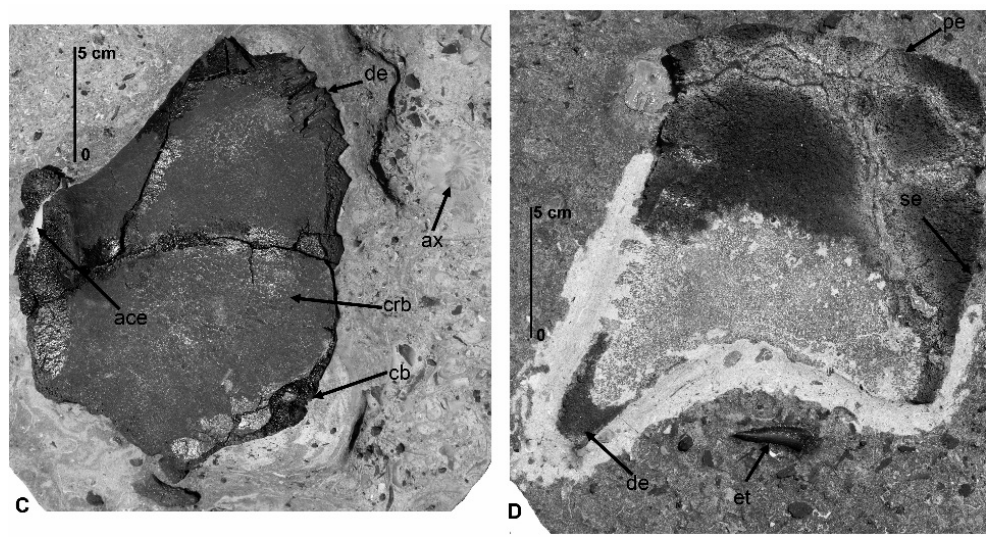

Figure 7. Turtle plastral elements from the basalmost Midway Group lag deposit Hot Spring County, Arkansas. (A) Partial plastron (NJSM GP23417) in exterior view; (B) partial plastron (NJSM GP23627) in exterior view; (C) partial plastron (NJSM GP23418) in interior view; (D) partial plastron (NJSM GP23412) in interior view. Scale bars in $\mathbf{A}-\mathbf{D}=5 \mathrm{~cm}$. Abbreviations: ace: acetabulum, ax: ammonite cross-section, de: distal edge, et: Enchodus tooth, pe: proximal edge, se: sutural edge.

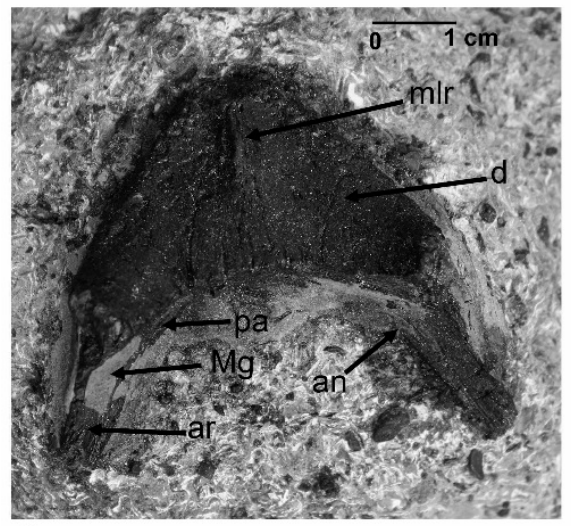

A

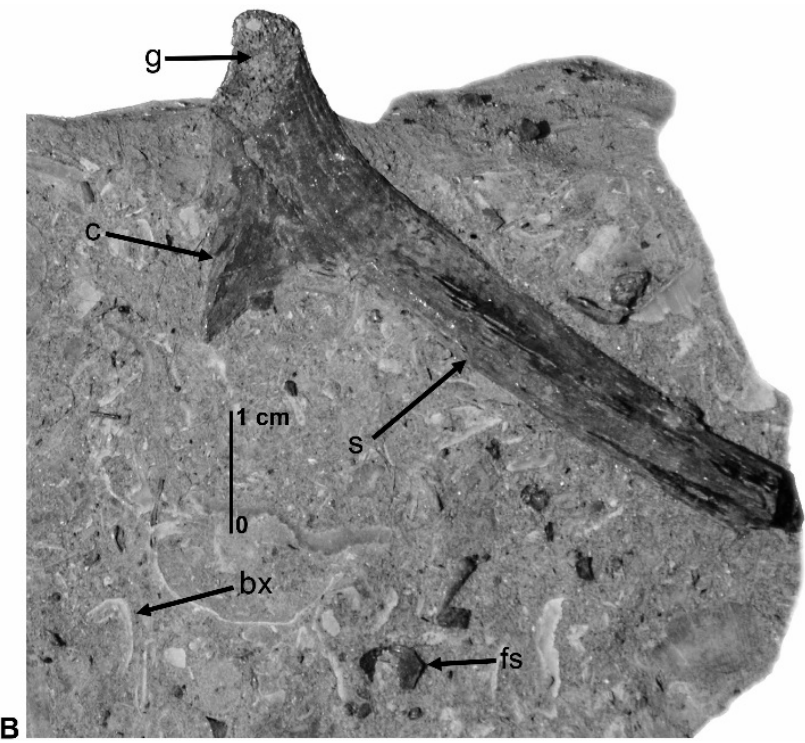

Figure 8. Turtle mandible and shoulder girdle from the basalmost Midway Group lag deposit Hot Spring County, Arkansas. (A) Mandible (NJSM GP23409) in interior view; (B) shoulder girdle (NJSM GP23400) in interior view. Scale bars in $\mathbf{A}$ and $\mathbf{B}=1 \mathrm{~cm}$. Abbreviations: an: angular, ar: articular, bx: bivalve cross-section, c: coracoid, d: dentary, fs: fish scale, g: glenoid, Mg: Meckelian groove, mlr: midline ridge, pa: prearticular, s: scapula.

\section{Turtle Assemblage}

The nineteen turtle specimens occurring in the Malvern lag deposit represent single bones from multiple individuals, the majority of which are preserved on separate coquina blocks. The assemblage consists of common carapace and plastral elements (Figures 4-7), and a nearly complete mandible and partial shoulder girdle (Figure 8).

Although the bones are fragmentary, the overall size, shape and thickness, sutural edges, and surface sculpturing are distinct to turtles, and, based on these features, represent different turtle species. However, we refrain from any taxonomic identification due to the lack of multiple skeletal elements that can be attributed to the same individual and to the fragmentary nature of individual bones. 
The two neural bones and five peripherals show distinct sutural edges for articulation to adjoining peripherals; a sulcus groove from overlaying scutes; a ventral keel for vertebral articulation, and a foramen for articulation to the distal rib projection (Figure 4). The eight costals show distinct sutural edges for articulation to adjacent costals and neurals, surface sculpturing, distal projections for articulation to adjoining peripherals, a sulcus groove from overlaying scutes, and a partial rib head for vertebral articulation (Figures 5 and 6). The four plastral elements show sutural edges, proximal and distal projections and a partial acetabulum (Figure 7). The near complete mandible in interior view shows the dentary with mid-line cusp, as well as the Meckelian groove, prearticular, angular and articular regions (Figure 8). The partial shoulder girdle shown in Figure 8 includes the scapula, coracoid, and glenoid. In general, the Malvern turtle assemblage resembles late Cretaceous and early Paleocene turtle genera found in overlapping but different habitats including open marine environments, the littoral zone, estuaries and rivers (e.g., [18-24]).

Some examples of these contemporaneous turtle genera described from more complete and articulated specimens in the Atlantic and Gulf Coastal Plains of North America include: Taphrospys, Catapleura, Euclastes, Adocus and Trionyx.

\section{Discussion}

\subsection{Origin of the Turtle Lag Deposit}

The Malvern lag deposit containing the turtle assemblage described in this report occurs within a coquina lag directly above a disconformity that marks the contact between the uppermost Arkadelphia Formation and basalmost Midway Group. The turtle fossils within this lag deposit all show different degrees of taphonomic wear, with partial erosion of cortical bone and exposure of cancellous bone in some specimens (Figure 4E,F, Figures 6A and 7B,D), and occur with chondrichthyans and osteichthyans as well as ammonites, gastropods and bivalves (Figure 4G, Figure 5A,C,D, Figure 6B, Figure 7C,D and Figure 8B).

Because this lag deposit also occurs at the boundary between the Maastrichtian and Paleocene, the Malvern turtles described in this report, along with other vertebrates were living at or near the time of the K-Pg mass extinction. Accordingly, the Malvern lag deposit is significant in that the concentration of turtle fossils and other vertebrates may record the effects of: (1) impact generated tsunamis as previously identified along the K-Pg boundary in the Gulf Coastal Plain; (2) third order eustatic sea level change in the latest Cretaceous; or (3) combined impact generated tsunamis and sea level cyclicity. Below, we discuss these three scenarios but note that current evidence does not yet allow us to distinguish among these alternative origins for the Malvern turtle lag.

\subsection{Impact Generated Tsunamis for Lag Deposit Formation}

In the Gulf of Mexico, the current view is that K-Pg tsunami deposits are the result of a bolide impact on the edge of the Yucatan Peninsula (e.g., [7,25-33]). Some of the key characteristics identified by these researchers for recognizing these deposits in outcrop that are also seen in the Malvern lag include: (1) a strong erosional base associated with scouring; (2) pebble conglomerates, reworked blocks and coquina accumulations; (3) mixing of fossils coming from different environments; and (4) rapid lateral changes in facies.

At a site near the outcrop section depicted in Figure 2, Larina et al. [7] recently compiled a nine meter measured section utilizing ammonites, dinoflagellates and calcareous nannofossils to trace the continuity of the K-Pg boundary across the Mississippi Embayment and Gulf Coastal Plain. Their measured section also identified a prominent disconformity and lag deposit at the top of the Arkadelphia Formation and basalmost Midway Group that they interpret to represent impact generated tsunamis [7]. This interpretation is also consistent with the observation that macrofossils within the Malvern section belong to groups such as ammonites and plesiosaurs that are generally thought to go extinct by the end of the Maastrichtian $[4,5,7]$. 


\subsection{Third Order Sea Level Generated Lag Deposits}

Prior models of lag deposit formation during the Late Cretaceous and Cenozoic of North America indicate that many concentrations of vertebrate fossils occur at the boundary between third order sea level cycles (e.g., [34-43]). These sea level cycles can be recognized in outcrop by disconformities and lag deposits that occur along geologic contacts between clay-dominated and sand or limestone dominated lithologies (e.g., [44-46]). Vertebrate fossils concentrated in these lags can differ on the order of several million years and represent organisms with different habitat preferences (e.g., [37,46,47]).

Eustatic sea level cycles of Haq [48] identify a total of five minor to medium amplitude regressive-transgressive events during the Maastrichtian. Sea level fluctuation during these five events ranged between 25 and $75 \mathrm{~m}$, with the largest event KMa5, occurring just below the K-Pg boundary [48]. Similar sea level cycles are also identified in the northern Gulf Coastal Plain by Mancini et al. [49] and Mancini and Puckett [50]. During the early late Maastrichtian in the northwestern Gulf Coastal Plain, their research documents a regressive sea level interval followed by an erosional hiatus leading into the Paleocene. Duration of Maastrichtian sea level cycles identified by Haq [48] averages 1-2 million years. It is also noteworthy that Haq [48] identified condensed section deposits that contain shell and bone beds similar to the Malvern turtle lag described in this report as key features for identifying transgressive facies, stratigraphic correlation, and construction of third order sea level cycles for the Cretaceous. In this regard, it is possible that a similar third-order sea level event accounts for the Malvern turtle lag.

\subsection{Combined Impact Generated Tsunamis and Third Order Sea Level Cyclicity}

It is also possible that impact generated tsunamis and regional sea level events could act in combination to produce the Malvern turtle lag deposit identified in this report. A case in point is a microspherulitic lag that occurs at the base of the Danian Clayton Formation in southeastern Missouri. This lag was originally interpreted by Campbell et al. [31] and Oboh-Ikeunobe et al. [33] as the result of an end-Cretaceous tsunami. However, dinoflagellates preserved in these beds show that the lag is actually the product of an early Danian sea level cyclicity event in which erosion exhumed and re-deposited both Maastrichtian macrofossils and end-Cretaceous impact spherules [51]. Of all the tsunamites yet examined in the Gulf Coastal Plain, this one is geographically closest to Malvern.

\section{Future Research}

Determining the exact origin of the Malvern turtle lag relies on detailed timing of biostratigraphically significant fossils through the section. To date, no vertebrate fossils known exclusively from the Paleocene are present in the Malvern turtle lag or in the beds that reside directly above. However, chondrichthyans and osteichthyans from the Paleocene have been identified and described in nearby sections of the Midway Group approximately $3 \mathrm{~km}$ to the northeast along strike from the Malvern locality by Becker et al. [11] and Becker and Chamberlain [12]. While a latest Maastrichtian age assignment for the Malvern section is provided by Larina et al. [7] based on ammonites and calcareous nannofossils, no vertebrates or Danian microfossils are identified in their study. However, Larina et al. [7] indicated that the lag comprising the basalmost Midway Group at the Malvern site contains abundant impact spherules.

A critical, but as yet unperformed, line of research that potentially could resolve a single origin or combined origin scenario presented above is the distribution of dinoflagellates and impact spherules through the Malvern turtle lag section. We are currently processing these sediments in order to refine the timeframe recorded by the Malvern turtle lag. A rapid or prolonged origin for the formation of this lag may favor one of the three scenarios presented above. Nevertheless, stratigraphic evidence indicates the turtle assemblage found in the Malvern lag contains the remains of individuals that were living at or near the time of the K-Pg mass extinction and represent some of the latest Cretaceous turtles yet recovered from the Gulf Coastal Plain of the United States. 
Acknowledgments: We thank David Parris and Rodrigo Pellegrini of the New Jersey State Museum for assistance with specimen identification and establishing a repository for the turtle specimens in this report. Ralph Scimeca of William Paterson University provided assistance with figure preparation. James Sloan of the Arkansas Highway and Transportation Department assisted with access to the Midway Group outcrop exposure adjacent to the nearby interstate. Four anonymous reviewers improved an earlier version of this manuscript. This research was supported in part by Assigned Release Time and Center for Research Grants from William Paterson University to Martin A. Becker, and by Professional Staff Congress-City University of New York awards to John A. Chamberlain.

Author Contributions: Martin A. Becker and Harry M. Maisch performed the field work; Martin A. Becker identified the turtle specimens; and Martin A. Becker, John A. Chamberlain, and Harry M. Maisch wrote the paper.

Conflicts of Interest: The authors declare no conflict of interest. Funding sponsors had no role in the design of the study; in the collection, analyses, or interpretation of data; in the writing of the manuscript; or in the decision to publish the results.

\section{References}

1. Schmidt, K. A new turtle of the Genus Podocnemis from the Cretaceous of Arkansas. Field Mus. Nat. Hist. Geol. Ser. 1940, 8, 1-12.

2. Schmidt, K. Two new Thalassemyd turtles from the Cretaceous of Arkansas. Field Mus. Nat. Hist. Geol. Ser. 1944, 8, 63-74.

3. Becker, M.; Chamberlain, J., Jr.; Wolf, G. Chondrichthyans from the Arkadelphia Formation (Upper Cretaceous: Upper Maastrichtian) of Hot Spring County, Arkansas. J. Paleontol. 2006, 80, 700-716. [CrossRef]

4. Becker, M.; Mallery, C., Jr.; Chamberlain, J., Jr. Osteichthyans from an Arkadelphia Formation-Midway Group lag deposit (Late Maastrichtian-Paleocene), Hot Spring County, Arkansas, U.S.A. J. Vertebr. Paleontol. 2010, 30, 1019-1036. [CrossRef]

5. Becker, M.; Maisch, H., IV; Chamberlain, J., Jr. Plesiosaurian remains from the Arkadelphia Formation-Midway Group contact (Maastrichtian-Paleocene) Hot Spring County, near Malvern, Arkansas, U.S.A. Paludicola 2013, 9, 131-143.

6. Cushman, J. The foraminiferal fauna of the Upper Cretaceous Arkadelphia marl of Arkansas. U.S. Geol. Surv. Prof. Pap. 1949, 221, 1-19.

7. Larina, E.; Garb, M.; Landman, N.; Dastas, N.; Thibault, N.; Edwards, L.; Phillips, G.; Rovelli, R.; Myers, C.; Naujokaityte, J. Upper Maastrichtian ammonite biostratigraphy of the Gulf Coastal Plain (Mississippi Embayment, southern USA). Cretac. Res. 2016, 60, 128-151. [CrossRef]

8. Jones, E. Palynology of the Midway-Wilcox boundary in south-central Arkansas. Gulf Coast Assoc. Geol. Soc. Trans. 1962, 12, 285-294.

9. Dastas, N.; Chamberlain, J., Jr.; Becker, M. Palynomorphs of the Arkadelphia Formation and Midway Group transition (Maastrichtian-Danian), Hot Spring County, Arkansas. Geol. Soc. Am. Abstr. Programs 2010, 42, 185.

10. Pitakpaivan, K.; Hazel, J. Ostracods and chronostratigraphic position of the Upper Cretaceous Arkadelphia Formation of Arkansas. J. Paleontol. 1994, 68, 111-122. [CrossRef]

11. Becker, M.; Smith, L.; Chamberlain, J., Jr. Chondrichthyans from the Clayton Limestone unit of the Midway Group (Paleogene: Paleocene) of Hot Spring County, Arkansas. Cainozoic Res. 2011, 8, 1-15.

12. Becker, M.; Chamberlain, J., Jr. Osteichthyans from the Paleocene Clayton Limestone of the Midway Group, Hot Spring County, Arkansas, U.S.A.: Bony fish evolution across the Cretaceous-Paleogene boundary. Paludicola 2012, 4, 194-207.

13. Liddicoat, J.; Hazel, J.; Brouwers, E. Magnetostratigraphy of Upper Cretaceous deposits in southwestern Arkansas and northeastern Texas. AAPG Bull. 1981, 65, 764-765.

14. Haley, B.; Glick, E.; Bush, W.; Clardy, B.; Stone, C.; Woodward, M.; Zachry, D. Geologic Map of Arkansas. 1:500,000 Scale, 1 Sheet; Arkansas Geologic Commission: Little Rock, AR, USA, 1993.

15. Haley, B.; Stone, C.; Clardy, B.; Hanson, W. Geologic Map of the Arkadelphia, Quadrangle, Clark, Garland, Hempstead, Hot Spring, Howard, Montgomery, Pike, and Polk Counties, Arkansas. 1:100,000 Scale, DGM-AR-01100; Arkansas Geologic Commission: Little Rock, AR, USA, 2009.

16. McFarland, J. Stratigraphic Summary of Arkansas; Information Circular; Arkansas Geological Commission: Little Rock, AR, USA, 2004; Volume 36, p. 44.

17. Sloan, J. (Arkansas Highway and Transportation Department, Fayetteville, AR, USA). Personal communication, 2015.

18. Ernst, C.; Barbour, R. Turtles of the World; Smithsonian Institution Press: Washington, DC, USA, 1989 ; p. 313. 
19. Hirayama, R.; Brinkman, D.; Danilov, I. Distribution and biogeography of non marine Cretaceous turtles. Russ. J. Herpetol. 2000, 7, 181-198.

20. Holroyd, P.; Hutchison, J. Patterns of geographic variation in latest Cretaceous vertebrates: Evidence from the turtle component. Geol. Soc. Am. Spec. Pap. 2002, 361, 177-190.

21. Hutchison, J.; Holroyd, P. Late Cretaceous and early Paleocene turtles of the Denver Basin, Colorado. Rocky Mt. Geol. 2003, 38, 121-142. [CrossRef]

22. Brinkman, D.B.; Rodriguez-de la Rosa, R.A. Non-marine turtles from the Cerro Del Pueblo Formation (Campanian), Coahuila State, Mexico. N. M. Mus. Nat. Hist. Sci. Bull. 2006, 35, 229-233.

23. Jalil, N.; de Broin, F.; Bardet, N.; Vacant, R.; Bouya, B.; Amaghzaz, M.; Meslouh, S. Euclastes acutirostris, a new species of littoral turtle (Cryptodira, Cheloniidae) from the Palaeocene phosphates of Morocco (Oulad Abdoun Basin, Danian-Thanetian). C. R. Palevol 2009, 8, 447-459. [CrossRef]

24. Brinkman, D.; Holroyd, P.; Gardner, J. Morphology and Evolution of Turtles; Springer Science and Business Media: Dordrecht, The Netherlands, 2012; p. 577.

25. Bourgeois, J.; Hansen, T.; Wiberg, P.; Kauffman, E. A tsunami deposit at the Cretaceous-Tertiary boundary in Texas. Science 1988, 241, 567-570. [CrossRef] [PubMed]

26. Pitakpaivan, K.; Byerly, G.; Hazel, J. Pseudomorphs of impact spherules from a Cretaceous-Tertiary boundary section at Shell Creek, Alabama. Earth Planet. Sci. Lett. 1994, 124, 49-56. [CrossRef]

27. Olsson, R.; Liu, C.; van Fossen, M. The Cretaceous-Tertiary catastrophic event at Millers Ferry, Alabama. In The Cretaceous-Tertiary Boundary Event and Other Catastrophes in Earth History; Ryder, G., Fastovsky, D., Gartner, S., Eds.; Special Paper 307; Geological Society of America: Boulder, CO, USA, 1996; pp. 263-277.

28. Smit, J.; Alvarez, W.; Montanari, A.; Claeys, P.; Grajales-Nishimura, J. Coarse-grained, clastic sandstone complex at the K/T boundary around the Gulf of Mexico: Deposition by tsunami waves induced by the Chicxulub impact? In The Cretaceous-Tertiary Boundary Event and Other Catastrophes in Earth History; Ryder, G., Fastovsky, D., Gartner, S., Eds.; Special Paper 307; Geological Society of America: Boulder, CO, USA, 1996; pp. 151-182.

29. Lawton, T.; Shipley, K.; Aschoff, J.; Giles, K.; Vega, F. Basinward transport of Chicxulub ejecta by tsunami-induced backflow, La Popa basin, northeastern Mexico, and its implications for distribution of impact-related deposits flanking the Gulf of Mexico. Geology 2005, 33, 81-84. [CrossRef]

30. Schulte, P.; Speijer, R.; Mai, H.; Kontny, A. The Cretaceous-Paleogene (K-P) boundary at Brazos, Texas: Sequence stratigraphy, depositional events and the Chicxulub impact. Sediment. Geol. 2006, 184, 77-109. [CrossRef]

31. Campbell, C.; Oboh-Ikuenobe, F.; Eifert, T. Megatsunami Deposit in Cretaceous Paleogene Boundary Interval of Southeastern Missouri. Geol. Soc. Am. Spec. Pap. 2008, 437, 189-198.

32. Miller, K.; Sherrell, R.; Browning, J.; Field, M.; Gallagher, W.; Olsson, R.; Sugarman, P.; Tuorto, S.; Wahyudi, H. Relationship between mass extinction and iridium across the Cretaceous-Paleogene boundary in New Jersey. Geology 2010, 38, 867-870. [CrossRef]

33. Oboh-Ikuenobe, F.; Spencer, M.; Campbell, C.; Haselwander, R. A portrait of Late Maastrichtian and Paleocene palynoflora and paleoenvironment in the northern Mississippi Embayment, southeastern Missouri. Palynology 2012, 36, 63-79. [CrossRef]

34. Case, G.; Schwimmer, D. Late Cretaceous fish from the Blufftown Formation (Campanian) in western Georgia. J. Paleontol. 1988, 62, 290-301. [CrossRef]

35. Eaton, J.; Kirkland, J.; Kentaro, D. Evidence of reworked Cretaceous fossils and their bearing on the existence of Tertiary dinosaurs. Palaios 1989, 4, 281-286. [CrossRef]

36. Ward, D.; Wiest, R. A checklist of Paleocene and Eocene sharks and rays (Chondrichthyes) from the Pamunkey Group, Maryland and Virginia, USA. Tert. Res. 1990, 12, 81-88.

37. Kidwell, S. Influence of subsidence on the anatomy of marine siliciclastic sequences and on the distribution of shell and bone beds. J. Geol. Soc. Lond. 1993, 150, 165-167. [CrossRef]

38. Becker, M.; Slattery, W.; Chamberlain, J., Jr. Reworked Campanian and Maastrichtian macrofossils in a sequence bounding, transgressive lag deposit, Monmouth County, New Jersey. Northeast. Geol. Environ. Sci. 1996, 18, 234-252.

39. Becker, M.; Slattery, W.; Chamberlain, J., Jr. Reworked chondrichthyan teeth from the Blufftown and Tombigbee Sands (Upper Cretaceous) of the eastern Gulf Coastal Plain. Southeast. Geol. 1998, 37, $205-216$. 
40. Burris, J. Reworked Cretaceous elasmobranch teeth and provenance of the Paleocene Hanna Formation (Hanna Basin, Wyoming). Rocky Mt. Geol. 2001, 36, 37-48. [CrossRef]

41. Manning, E. The Eocene/Oligocene transition in marine vertebrates of the Gulf Coastal Plain. In From Greenhouse to Icehouse, the Marine Eocene-Oligocene Transition; Prothero, D.R., Ivany, L.C., Nesbitt, E.A., Eds.; Columbia University Press: New York, NY, USA, 2003; pp. 366-385.

42. Shimada, K.; Schumacher, B.; Parkin, J.; Palermo, J. Fossil marine vertebrates from the lowermost Greenhorn Limestone (Upper Cretaceous: Middle Cenomanian) in southeastern Colorado. J. Paleontol. 2006, 80, 1-45. [CrossRef]

43. Maisch, H., IV; Becker, M.; Raines, B.; Chamberlain, J., Jr. Osteichthyans from the Tallahatta-Lisbon Formation Contact (middle Eocene-Lutetian) Pigeon Creek, Conecuh Covington Counties, Alabama with Comments on Transatlantic Occurrences in the Northern Atlantic Ocean Basin. PalArch's J. Vertebr. Palaeontol. 2016, 13, 1-22.

44. Mancini, E.; Tew, B. Claiborne-Jackson Group contact (Eocene) in Alabama and Mississippi. Gulf Coast Assoc. Geol. Soc. Trans. 1994, 44, 431-439.

45. Clayton, A.; Ciampaglio, C.; Cicimurri, D. An inquiry into the stratigraphic occurrence of a Claibornian (Eocene) vertebrate fauna from Covington County, Alabama. Bull. Ala. Mus. Nat. Hist. 2013, 31, 60-73.

46. Boessenecker, R.; Perry, F.; Schmitt, J. Comparative taphonomy, taphofacies, and bonebeds of the Mio-Pliocene Purisima Formation, Central California: Strong physical control on marine vertebrate preservation in shallow marine settings. PLoS ONE 2014, 9, e91419. [CrossRef] [PubMed]

47. Maisch, H., IV; Becker, M.; Raines, B.; Chamberlain, J., Jr. Chondrichthyans from the Tallahatta-Lisbon Formation contact (middle Eocene), Silas, Choctaw County, Alabama. Paludicola 2014, 9, 183-209.

48. Haq, B. Cretaceous eustasy revisited. Glob. Planet. Chang. 2014, 113, 44-58. [CrossRef]

49. Mancini, E.; Puckett, T.; Tew, B.; Smith, C. Upper Cretaceous sequence stratigraphy of the Mississippi-Alabama area. Gulf Coast Assoc. Geol. Soc. Trans. 1995, 45, 377-384.

50. Mancini, E.; Puckett, T. Jurassic and Cretaceous transgressive-regressive (TR) cycles, northern Gulf of Mexico, USA. Stratigraphy 2005, 2, 31-48.

51. Dastas, N.; Chamberlain, J.; Garb, M. Cretaceous-Paleogene Dinoflagellate Biostratigraphy and the Age of the Clayton Formation, Southeastern Missouri, USA. Geosciences 2014, 4, 1-29. [CrossRef]

(C) 2016 by the authors; licensee MDPI, Basel, Switzerland. This article is an open access article distributed under the terms and conditions of the Creative Commons Attribution (CC-BY) license (http://creativecommons.org/licenses/by/4.0/). 